\title{
ZIG-ZAG RUN: METODE LATIHAN KELINCAHAN TENDANGAN SABIT PENCAK SILAT
}

\author{
Tofikin $^{* 1}$, Ridwan Sinurat ${ }^{2}$ \\ STKIP Rokania, Indonesia ${ }^{* 1}$, Universitas Pasir Pangarian, Indonesia ${ }^{2}$ \\ Email: tofikinkin86@gmail.com ${ }^{* 1}$, indonsinurat@gmail.com ${ }^{2}$
}

Received: 25 July 2020; Accepted 03 November 2020; Published 01 December 2020

Ed 2020; 5(2): 177-185

\begin{abstract}
ABSTRAK
Metode latihan saat ini belum terfokus dalam meningkatkan kondisi fisik yang dapat meningkatkan kemampuan teknik dasar pencak silat. Tujuan penelitian ini adalah untuk mengetahui pengaruh latihan zigzag run terhadap kelincahan tendangan sabit atlet pencak silat Pencak Silat Persaudraan Setia Hati Terate. Jenis penelitian yang digunakan adalah penelitian eksperimen yaitu suatu jenis penelitian yang dimaksudkan untuk mencari pengaruh perlakuan tertentu terhadap yang lain dalam kondisi yang terkendalikan. Eksperimen dalam penelitian ini lebih bersifat pra-eksperimental jenis pre-test dan pos-test dalam suatu kelompok. Teknik pengambilan sampel mengunakan sampel jenuh dengan jumlah sampel sebanyak 19 atlet. Hasil penelitian bahwa latihan zig-zag run berpengaruh terhadap kelincahan tendangan sabit pada atlet Pencak Silat Persaudaraan Setia Hati Terate di Kabupaten Rokan Hulu. Dari hasil analisis data peneliti merekomendasikan untuk penelitian ke depannya yaitu kondisi fisik daya ledak otot tungkai dan kecepatan agar kelincahan tendangan sabit dapat lebih maksimal dilakukan.
\end{abstract}

Kata Kunci: Zig-Zag Run; Kelincahan; Tendangan Sabit; Pencak Silat

\section{ZIG-ZAG RUN: METHOD FOR AGILITY TRAINING OF THE PENCAK SILAT SABIT KICKING}

\begin{abstract}
Method of training currently has not focused in improving physical conditions that can improve the ability of basic techniques of Pencak Silat. The purpose of this study was to determine the effect of zig-zag run training on the crescent-kick agility of Persaudraan Setia Hati Terate's Pencak Silat athletes. The type of research used experimental research, which is a type of research that is intended to seek the effect of certain treatments on others under controlled conditions. Experiments in this study are more pre-experimental types of pre-test and post-test in a group. The sampling technique used saturated samples with a sample amount of 19 athletes. The results showed that training of zig-zag run had an effect on the agility of the sickle kick in Setia Hati Terate Persaudaraan Pencak Silat athlete in Rokan Hulu Regency. From the results of the data analysis, the researcher recommends for the future study, namely the physical condition of the leg muscle explosive power and speed so that the agility of the sickle kick can be maximized.
\end{abstract}

Keyword: Zig-Zag Run; Agility; Crescent Kick; Pencak Silat

Copyright (C) 2020, Journal Sport Area

DOI: https://doi.org/10.25299/sportarea.2020.vol5(2).5333

How To Cite: Tofikin \& Sinurat, R. (2020). Zig-Zag Run: Metode Latihan Kelincahan Tendangan Sabit Pencak Silat. Journal Sport Area, 5(2), 177-185.

\section{PENDAHULUAN}

Pencak silat merupakan olahraga beladiri yang telah menjadi budaya bangsa Indonesia yang digunakan untuk membela atau mempertahankan diri dari serangan lawan selain itu juga merupakan olahraga prestasi yang dipertandingkan baik di tingkat daerah, nasional maupun internasional mulai dari tingkat anak-anak sampai ke tingkat dewasa, baik 
pelajar maupun umum (Kuswanto, 2016). Beberapa hal yang akan dibentuk ketika seseorang mengikuti latihan pencak silat di antaranya adalah terbentuknya kondisi tubuh yang sehat. Lebih lanjut diterangkan oleh Shafie (2014) bahwa komponen fisik harusnya sudah dimulai dikembangkan dan diterapkan untuk atlet remaja atau muda pencak silat yang mana arahnya akan menuju puncak prestasi.

Pencak silat merupakan olahraga yang dominan dengan kontak fisik, selain diajarkan metode beladiri, pencak silat juga menyelipkan nilai-nilai budi pekerti yang luhur yang diperlukan untuk mewujudkan cita-cita agama dan membentuk moral masyarakat yang baik (Wilujeng, 2013). Budi pekerti luhur merupakan aspek kejiwaan dan watak atau akhlak yang baik yang perlu dimiliki seseorang. Falsafah budi pekerti luhur mengajarkan manusia sebagai mahluk tuhan, mahluk pribadi, mahluk sosial dan mahluk alam semesta yang selalu mengamalkan pada bidang masing-masing sesuai dengan cipta, rasa, dan karsanya yang mulia.

Untuk memperoleh prestasi pencak silat selain ditanamkan sifat yang berbudi pekerti luhur atlet harus melakukan latihan secara terprogram sehingga dapat menguasai teknik dasar dengan baik. Teknik dasar yang harus dilatih seperti teknik kuda-kuda, elaan dan serangan. Teknik serangan dapat dilakukan dengan mengunakan tangan atau sering disebut pukulan dan mengunakan kaki sering disebut tendangan (Dewi, 2014). Menurut Iswana \& Siswantoyo (2013) tendangan yaitu serangan yang dilakukan dengan menggunakan kaki, mengena pada bagian yang sah sesuai dengan peraturan pertandingan. Teknik ini memiliki keistimewaan yaitu memimiliki kekuatan yang lebih besar, memiliki jangkauan yang lebih jauh dan memiliki nilai yang besar serta pelaksanaanya yang mudah dilakukan.

Tendangan sabit merupakan salah satu teknik serangan dengan kaki yang ada dalam ajaran pencak silat. Menurut Tofikin (2020) tendangan sabit adalah tendangan yang dilakukan dengan cara menendangakan kaki dengan arah membentuk setengah lingkaran ke dalam dengan perkenaan punggung kaki. Tendangan ini sangat mudah dilakukan dan apabila pesilat dapat mampu melakukan suatu tendangan dan mengenai sasaran maka pesilat akan mendapatkan skor 2. Kemudian Kuswanto (2016) menjelaskan tendangan sabit adalah tendangan yang lintasanya menyerupai sabit atau setengah lingkaran dengan arah ke dalam dengan sasaran seluruh bagian tubuh dengan perkenaan punggung kaki. Selanjutnya Pomatahu (2017) menjelaskan tendangan sabit adalah tendangan yang dilakukan dengan lintasan melengkung seperti sabit dan fokusnya ada di kaki belakang. Tendangan ini bisa dilakukan dengan posisi kaki di depan atau di belakang juga bisa berbeda dengan lompatannya.

Agar tendangan sabit tidak mudah ditangkap maka harus dilakukan dengan lincah. Menurut Humaidi dan Wahyudi (2017) menjelaskan kelincahan (agility) adalah kemampuan tubuh untuk mengubah arah secara cepat tanpa adanya gangguan keseimbangan atau kehilangan keseimbangan. Kemudian Apri (2012) juga menjelaskan bahwa kelincahan adalah kemampuan seseorang untuk mengubah arah dengan cepat dan tepat pada waktu bergerak tanpa kehilangan keseimbangan. Selain kelincahan digunakan untuk teknik merubah arah gerakan sambil melakukan serangan, kelincahan juga merupakan prasyarat untuk mempelajari dan memperbaiki keterampilan gerak dan teknik olahraga terutama gerakan-gerakan yang membutuhkan koordinasi gerakan (Daryanto \& Hidayat, 2015). Kemudian lebih ditekankan Tofikin, Damrah, dan Nurmai (2019) bahwa kelincahan juga untuk mengantisipasi pergerakan lawan yang selalu berubah, sehingga 
dengan memiliki kelincahan yang baik dan pesilat dapat melakukan serangan dengan tepat.

Pentingnya kelincahan dalam pencak silat maka harus dilatih dengan tepat dan terprogram dengan baik sehingga menghasilkan puncak prestasi yang dituju (Hostrup \& Bangsbo, 2017). Cara melatih kelincahan dapat dilakukan dengan cara lari belak-belok (zig-zag run). Adapun cara melakukanya atlet berlari belak-belok dengan cepat sebanyak 2-3 kali di antara beberapa titik jarak setiap titik sekitar 2 meter, hal ini bertujuan untuk melatih mengubah gerak tubuh arah berkelak-kelok. Latihan zig-zag run ini dijelaskan juga dalam penelitian Ahmad (2018) bahwa latihan zig-zag run berpengaruh terhadap kelincahan tendangan sabit. Demikian juga dijelaskan dari hasil penelitian Purba (2017) bahwa kelincahan gerak berpengaruh terhadap kecepatan tendangan. Sejalan dengan pendapat di atas, Mansur, Kurniawan, Irianto, dan Nurfadhila (2020) juga merekomendasikan bentuk latihan untuk meningkatkan kelincahan yaitu lari zig-zag (zigzag run).

Dari hasil observasi pada perguruan pencak silat Persaudaraan Setia Hati Terate terlihat metode latihan saat ini belum terfokus dalam meningkatkan kondisi fisik yang dapat meningkatkan kemampuan teknik dasar pencak silat. Sehingga saat bertandingan serangan mudah diantisipasi lawan. Pentingnya penelitian ini dilakukan karena kemampuan kelincahan tendangan sabit merupakan salah satu aspek yang sangat penting untuk olahraga pencak silat. Seseorang pesilat yang memiliki kemampuan kelincahan tendangan, memungkinkan seorang pesilat untuk melakukan serangan dari berbagai arah sehingga sulit untuk diantisipasi lawan dan serangan akan mudah masuk sasaran, oleh sebab itu kemampuan kelincahan tendangan harus diperhatikan dan dilatih secara terprogram dengan model latihan yang tepat. Hasil penelitian ini diharapkan dapat digunakan pelatih sebagai rujukan dalam meningkatkan kemampuan keterampilan pencak silat khususnya kelincahan tendangan sabit. Sehingga atlet pencak silat akan memproleh prestasi yang maksimal.

\section{METODE PENELITIAN}

Jenis penelitian yang digunakan adalah penelitian eksperimen yaitu suatu jenis penelitian yang dimaksudkan untuk mencari pengaruh perlakuan tertentu terhadap yang lain dalam kondisi yang terkendalikan (Sugiono, 2012). Eksperimen dalam penelitian ini lebih bersifat pra-eksperimental jenis pre-test dan pos-test dalam suatu kelompok.

Populasi dalam penelitian adalah atlet pencak silat Persaudaraan Setia Hati Terate di Kabupaten Rokan Hulu terdiri dari 19 atlet. Dikarenakan jumlah populasi yang sedikit maka seluruh populasi dijadikan sampel dengan teknik pengambilan sampel jenuh. Data yang dikumpulkan dalam penelitian ini yaitu data pre-test kelincahan tendangan sabit sebelum perlakuan dan data post-test setelah perlakuan.

Adapun instrumen dalam penelitian ini yaitu tes kelincahan tendangan sabit yang mana memiliki tujuan untuk mengetahui kemampuan kelincahan tendangan pencak silat atlet (untuk tendangan lurus, samping dan sabit). Alat yang digunakan yaitu sandsack (diharapkan berat $50 \mathrm{~kg}$ ), target (hand box), dan petugas penelitian yaitu pengukur ketinggian sandsack, pencatat waktu, dan penjaga sandsack. Untuk pelaksanaanya atlet bersiap-siap berdiri di belakang sandsack/target dengan dua kaki berada di tengah- tengah garis. Pada saat aba-aba ya atlet melakukan tendangan dengan kaki kanan dengan melompat, dimana kaki kiri sebagai kaki tumpu berada di garis kanan, kemudian melakukan sabit kiri dengan kaki kanan sebagai tumpuan yang berada di sebelah garis 
kiri. Setiap atlet melakukan tendangan kaki kanan dan kaki kiri sebanyak- banyaknya secara bergantian selama 15 detik. Pelaksanaan dilakukan 3 kali dan diambil waktu yang terbaik dengan ketingian sandsak/target $75 \mathrm{~cm}$ (puteri) dan $100 \mathrm{~cm}$ (putera) (Lubis \& Wardoyo, 2014). Norma kelincahan tendangan sabit dapat dilihat pada tabel 1.

Tabel 1. Norma Kelincahan Tendangan Sabit

\begin{tabular}{ccc}
\hline Kategori & Putri & Putra \\
\hline Baik sekali & $>28$ & $>30$ \\
Baik & $23-27$ & $25-29$ \\
Cukup & $18-22$ & $20-24$ \\
Kurang & $14-17$ & $15-19$ \\
Kurang sekali & $<13$ & $<14$ \\
\hline
\end{tabular}

(Lubis., 2014)

Langkah yang dilakukan dalam penerapan instrumen penelitian ini antara lain: (1) melakukan pre-test kelincahan tendangan sabit; (2) melakukan eksperimen atau perlakuan menggunakan latihan zig-zag run selama 14 kali pertemuan; (3) melakukan post-test kelincahan tendangan sabit; (4) menganalisis skor pre-test dan post-test dengan mengunakan rumus uji $t$; (5) membandingkan hasil analisis $t_{\text {hitung }}$ dengan skor $t_{\text {tabel }} ;(6)$ menyimpulkan latihan zig-zag run apakah memberikan pengaruh atau tidak terhadap kelincahan tendangan sabit. Teknik analisis data dalam penelitian ini mengunakan uji t.

Keterangan:

$$
t=\frac{M d}{\sqrt{\frac{\Sigma x^{2} d}{N(n-1)}}}
$$

Md = Mean (rata-rata) dari perbedaan pre test dengan post test

$\Sigma x^{2} d=$ Jumlah kuadrat deviasi

$\mathrm{N} \quad=$ Jumlah Sampel

\section{HASIL DAN PEMBAHASAN}

Berdasarkan dari hasil pengambilan data awal yaitu sebelum dilakukan perlakuan dengan metode latihan zig-zag run diberikan pre-test atau tes awal kelincahan tendangan sabit pencak silat terhadap 19 orang sampel dengan hasil skor yang terbaik 28 kali tendangan selama 15 detik, skor terendah sebesar 19 tendangan selama 15 detik, rata-rata (mean) sebesar 23 simpangan baku (standard deviasi) sebesar 2.560. Lebih jelasnya data dari tes awal (pre-test) tendangan sabit pencak silat dengan melakukan tendangan dengan kaki kiri dan kaki kanan sebanyak-banyaknya selama 15 detik dari 19 orang sampel dapat dilihat pada grafik1.

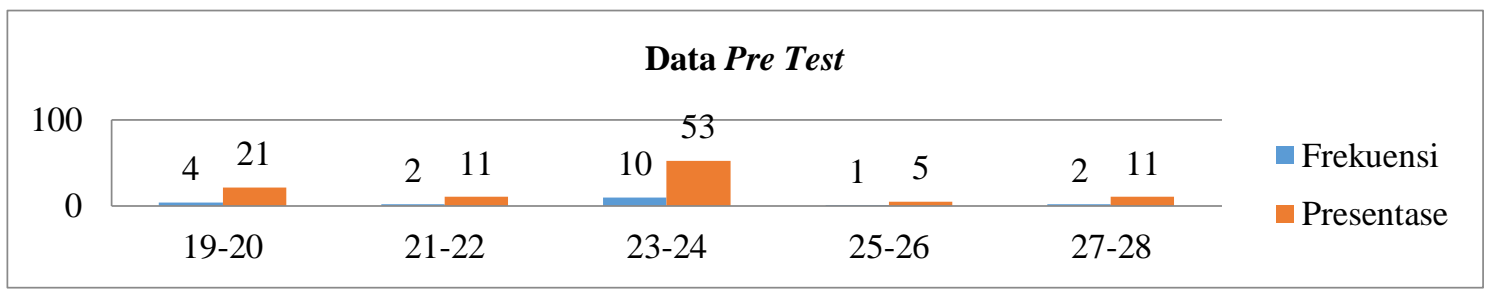

Grafik1. Nilai/Skor Tes Awal (Pre-Test) Kelincahan Tendangan Sabit Pencak Silat 
Berdasarkan grafik data dari tes awal (pre-test) kelincahan tendangan sabit pencak silat Persaudaraan Setia Hati Terate di Kabupaten Rokan Hulu dari 19 orang sampel diperoleh nilai/skor $19-20$ sebanyak 4 orang sampel atau $21 \%$, yang memiliki nilai/skor 21-22 sebanyak 2 orang sampel atau sebesar $11 \%$, yang memiliki skor/nilai 23-24 sebanyak 10 orang atau 53\%, yang memiliki skor/nilai 25-26 sebanyak 1 orang atau 5\% dan yang memiliki skor 27-28 sebanyak 2 orang atau $11 \%$. Berdasarkan data tersebut di atas, nilai/skor yang ada disesuaikan dengan tabel 2.

Tabel 2. Klasifikasi Nilai Skor Tes Awal Kelincahan Tendangan Sabit dengan Penilaian Kelincahan Tendangan Sabit

\begin{tabular}{cccc}
\hline No & Kategori & Prestasi & Frekuensi \\
\hline 1 & Baik sekali & $>25$ & - \\
2 & Baik & $20-24$ & 3 \\
3 & Cukup & $15-19$ & 13 \\
4 & Kurang & $10-14$ & 3 \\
5 & Kurang sekali & $<9$ & - \\
\hline
\end{tabular}

Berdasarkan hasil tes awal di lapangan, kemudian dimasukkan ke dalam penilaian di atas, terlihat bahwa distribusi frekuensi dari 19 sampel memiliki kelincahan tendangan sabit pencak silat yang dilakukan dengan cepat selama 15 detik diklasifikasikan dengan rata-rata cukup. Setelah perlakuan dengan metode latihan zig-zag run sebanyak 14 kali pertemuan, guna untuk meningkatkan tendangan sabit pencak silat, maka dilakukan tes akhir (post-test) dengan tes kelincahan tendangan sabit pencak silat selama 15 detik. Dari pengambilan data terhadap 19 orang sampel, didapat skor tertinggi yaitu dengan kaki kiri dan kaki kanan yaitu 32 kali tendangan selama 15 detik, dan skor terendah 23 kali tendangan selama 15 detik. Rata-rata (mean) sebesar 28, simpangan baku (standard deviasi) 2.807. Lebih jelasnya data tes akhir (post-test) tendangan sabit pencak silat dari 19 sampel dapat dilihat pada grafik 3 .

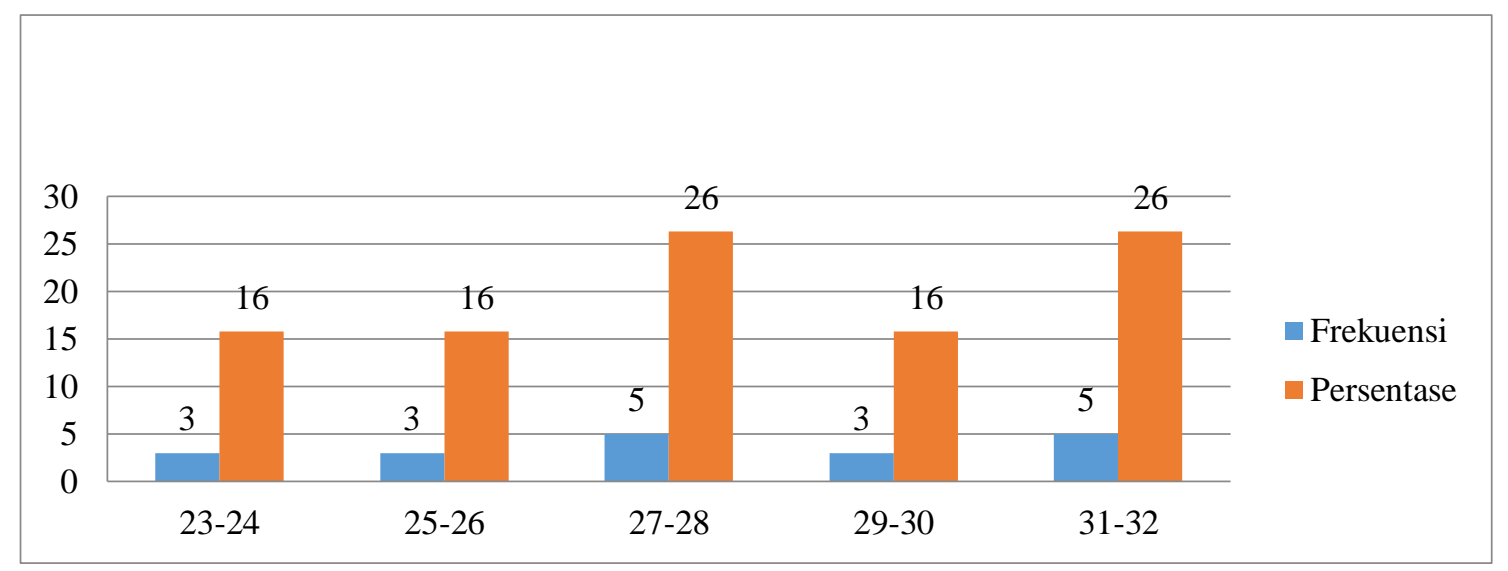

Grafik 2. Distribusi Frekvensi Nilai/Skor Tes Akhir (Post-Test) 
Berdasarkan tabel distribusi frekuensi data dari tes akhir (post-test) kelincahan tendangan sabit, dari 19 orang sampel diperoleh nilai skor 23-24 sebanyak 3 orang sampel atau 16\%, nilai/skor 25-26 sebanyak 3 orang sampel atau sebesar $16 \%$, nilai 27-28 sebanyak 5 orang sampel atau 26\%, nilai 29-30 sebanyak 3 orang sampel atau 16\% dan nilai 31-32 sebanyak 5 sampel atau 26\%. Berdasarkan data tersebut di atas, nilai/skor yang ada disesuaikan dengan tabel 3.

Tabel 3. Klasifikasi Nilai Skor Tes Akhir Kelincahan Tendangan Sabit dengan Penilaian Kelincahan Tendangan Pencak Silat

\begin{tabular}{ccc}
\hline Kategori & Prestasi & Frekuensi \\
\hline Baik sekali & $>30$ & 6 \\
Baik & $25-29$ & 11 \\
Cukup & $20-24$ & 2 \\
Kurang & $15-18$ & 0 \\
\hline Kurang sekali & $<14$ & 0 \\
\hline
\end{tabular}

Berdasarkan hasil tes akhir yang didapat di lapangan, kemudian dimasukkan ke dalam penilaian di atas, terlihat bahwa distribusi frekuensi dari 19 sampel memiliki kelincahan tendangan sabit pencak silat yang dilakukan dengan cepat selama 15 detik diklasifikasikan dengan rata-rata baik. Data yang terkumpul kemudian dianalisis, untuk variabel $\mathrm{X}$ adalah nilai/skor pre test dan yang menjadi variable $\mathrm{Y}$ skor post tes. Hipotesis yang diuji adalah 2 hipotesis yaitu hipotesis nihil dan hipotesis alternatif. Adapun tujuan dilakukan pembuktian hipotesis ini yaitu untuk melihat besarnya pengaruh independen variabel bebas yaitu latihan zig-zag run terhadap variabel terikat yaitu hasil kelincahan tendangan sabit. Hasil ini akan diuji taraf signifikan 95\%. Dengan demikian hasil analisis yang dapat disimpulkan bahwa latihan zig-zag run berpengaruh terhadap kelincahan tendangan sabit.

Maka untuk menguji apakah hipotesis yang diajukan dalam penelitian ini diterima kebenaranya atau tidak, maka dilakukan pengujian data dengan mengunakan rumus uji t. Berdasarkan perhitungan nilai t didapat $t_{\text {hitung }}=6,45$ kemudian dibandingkan dengan nilai t pada tabel distribusi nilai t di buku statistik dengan taraf signifikansi 5\%. Dari tabel $\mathrm{t}$ diketahui bahwa nilai $\mathrm{t}_{\text {tabel }}=1,73$ ini berarti bahwa $\mathrm{t}_{\text {hitung }}$ lebih besar dari $\mathrm{t}_{\text {tabel. }}$. Dengan demikian maka hipotesis penelitian Ho (hipotesis nol/awal) ditolak dan hipotesis Ha (hipotesis alternatif) diterima. Kemudian hasil menunjukkan terdapat pengaruh yang signifikan dan mempunyai peningkatan kemampuan sebesar 26,9\%. Berdasarkan hasil uji hipotesis tersebut maka dapat disimpulkan bahwa adanya pengaruh latihan zig-zag run terhadap kelincahan tendangan sabit pada siswa pencak silat Persaudaraan Setia Hati Terate di Kabupaten Rokan Hulu.

Tujuan penelitian ini adalah untuk mengetahui apakah latihan zig-zag run berpengaruh terhadap kelincahan tendangan sabit pada atlet pada pencak silat Persaudaraan setia Hati Terate di Kabupaten Rokan Hulu. Latihan zig-zag run dapat diartikan sebagai cara seseorang atau atlet melatih kelincahan dengan cara berlari dengan lintasan membentuk zigzag yang ditandai dengan kun. Dari hasil penelitian menunjukkan terdapat pengaruh yang signifikan dan mempunyai peningkatan kemampuan sebesar 26,9\%. Hal ini sejalan dengan hasil penelitian Ahmad (2018) yang menunjukkan bahwa metode latihan lari zig zag dapat meningkatkan kelincahan atlet pencak silat tapak suci Lebong. Kemudian Prasetyo (2017) juga menyatakan bahwa faktor kondisi fisik seperti kelincahan, kecepatan dan kekuatan adalah salah satu faktor yang mempengaruhi prestasi atlet. 
Senada dengan pendapat di atas Subekti, Sistiasih, Syaukani, dan Fatoni (2020) menyatakan bahwa peningkatan keterampilan pencak silat sangat dipengaruhi oleh kemampuan fisik dan keterampilan teknis yang merupakan kebutuhan yang harus dimiliki oleh setiap atlet pencak silat. Dari hasil penelitian dan pendapat ahli di atas maka dapat dijelaskan dengan melakukan latihan zig-zag run atlet akan dapat melakukan serangan dengan lincah dan bergerak ke segala arah sehingga serangan tidak mudah diantisipasi lawan, selain itu kondisi fisik seperti kelincahan, kecepatan dan kekuatan akan terbentuk dengan baik sehingga prestasi akan mudah diraih. Keterbatasan dalam penelitian ini adalah jumlah sampel yang sedikit hal ini dikarenakan karena adanya wabah virus covid 19 yang menyebabkan atlet banyak beraktivitas di rumah.

\section{KESIMPULAN}

Merujuk dari data yang telah didapat, dari hasil akhir penelitian dan pembahasan maka dapat disimpulkan bahwa terdapat pengaruh latihan zig-zag run terhadap kelincahan tendangan sabit pada atlet pencak silat Persaudaraan Setia Hati Terate di Kabupaten Rokan Hulu. Oleh sebab itu latihan zig-zag run dapat dijadikan sebagai model latihan untuk meningkatkan prestasi pencak silat terutama dalam meningkaatkan keterampilan pencak silat yaitu kelincahan tendangan sabit. Selain itu model latihan ini juga dapat meningkatkan faktor kondisi fisik yang menunjang kelincahan seperti kekuatan otot tungkai, kecepatan dan keseimbangan. Lebih lanjut atlet juga lebih termotivasi mengikuti latihan.

Selain memiliki kelebihan, metode latihan zig-zag run juga memiliki beberapa kelemahan di antaranya: (1) masih banyak atlet yang belum mengetahui metode latihan zig-zag run dan tes kelincahan tendangan sabit, (2) diperlukan kedisiplinan waktu latihan untuk semua atlet, (3) memerlukan tempat yang luas dan data dalam pelaksanaan latihan zig-zag run, (3) penjelasan dan pelaksaan metode latihan zig-zag run jauh dari kata sempurna dengan kekurangan pengetahuan metode latihan zig-zag run.

Mengingat pentingnya latihan zig-zag run terhadap kelincahan tendangan sabit, diharapkan kepada pelatih pencak silat Persaudaraan Setia Hati Terate di Kabupaten Rokan Hulu agar lebih memperhatikan metode latihan yang digunakan. Latihan ini bisa digunakan sebagai salah satu referensi pelatih untuk meningkatkan kelincahan tendangan sabit atlet pencak silat. Dari hasil analisis data peneliti merekomendasikan untuk penelitian ke depannya yaitu kondisi fisik daya ledak otot tungkai dan kecepatan agar kelincahan tendangan sabit dapat lebih maksimal dilakukan.

\section{DAFTAR PUSTAKA}

Ahmad, N. (2018). Pengaruh Latihan Zig Zag Run Terhadap Kelincahan Atlet Pencak Silat Tapak Suci Lebong. Journal Physical Education, Health and Recreation, 2(2), 181-185. https://doi.org/10.24114/pjkr.v2i2.9589

Apri, A. (2012). Olahraga Kebugaran Jasmani. Padang: Suka Bina Press.

Daryanto, Z. P., \& Hidayat, K. (2015). Pengaruh Latihan Kelincahan Terhadap Kemampuan Menggiring Bola. Jurnal Pendidikan Olahraga, 4(2), 201-212. http://dx.doi.org/10.31571/jpo.v4i2.87 
Dewi, A. K., \& (2014). Kontribusi Kelincahan Dan Kecepatan Terhadap Tendangan Sabit Pada Atlet Pencak Silat Putra Usia 12-14 Tahun. Jurnal Pendidikan Olahraga, 2(2), 158-163.

Hostrup, M., \& Bangsbo, J. (2017). Limitations in intense exercise performance of athletes - effect of speed endurance training on ion handling and fatigue development. Journal of Physiology, 9, 2897-2913. https://doi.org/10.1113/JP273218

Humaidi., \& Wahyudi, A. S. B. S. E. (2017). Sumbangan Kelincahan dan Keseimbangan Dinamis Terhadap Kemampuan Menggiring Bola Dalam Permainan Futsal Pada Mahasiswa PJKR. Journal Sport Sciences and Physical Education, 5(1), 80-94.

Iswana, B., \& Siswantoyo. (2013). Model Latihan Keterampilan Gerak Pencak Silat Anak Usia 9-12 Tahun. Jurnal Keolahragaan, 1(1), 26-36. https://doi.org/10.21831/jk.v1i1.2343

Kuswanto, C. W. (2016). Pengaruh Latihan Sprint di Pasir dan Sprint di Tempat Keras Terhadap Kecepatan Tendangan Sabit Kategori Tanding. Jorpres (Jurnal Olahraga Prestasi), 12(1), 63-77. https://doi.org/10.21831/jorpres.v12i1.9497

Lubis, J., \& Wardoyo, H. (2014). Pencak Silat. Jakarta: Raja Grafindo Persada.

Mansur., Kurniawan, F., Irianto, S., Herwin., \& Nurfadhila, R. (2020). Analisis kondisi fisik (kelincahan) atlet cabang olahraga unggulan Kabupaten Kebumen Provinsi Jawa Tengah. Jorpres (Jurnal Olahraga Prestasi), 16(2), 72-77. https://doi.org/10.21831/jorpres.v16i2.32929

Pomatahu, A. R. (2017). The relationship between leg length and crescent kick speed in pencak silat sport. International Journal of Sports Sciences \& Fitness, 2(25), 85-91. https://doi.org/10.23829/TSS.2018.25.2-4

Prasetyo, F. Y. (2017). The Physical Conditions of Pencak Silat Athletes The Physical Conditions of Pencak Silat Athletes. IOP Conference Series: Materials Science and Engineering PAPER, 180. https://doi.org/10.1088/1742-6596/755/1/011001

Purba, P. H. (2017). Hubungan kelentukan dan kelincahan terhadap kecepatan tendangan mawashi gery chudan pada karateka perguruan wadokai dojo UNIMED. Jurnal Prestasi, 1(1), 11-16. https://doi.org/10.24114/jp.v1i1.6492

Shafie, M. N. (2014). Fitness Characteristics of Youth Silat Performers. Malaysian Journal of Sport Science and Recreation, 10(1), 40-53.

Subekti, N., Sistiasih, V. S., Syaukani, A, A., \& Fatoni, M. (2020). Kicking ability in pencak silat, reviewed from eye-foot coordination, speed, and ratio of limb lengthbody height. Journal Of Human Sport \& Exercise, 15(2), 453-461. https://doi.org/10.14198/jhse.2020.15.Proc2.36 
Sugiono. (2012). Metode Penelitian Pendidikan. Bandung: Alfabeta.

Tofikin. (2020). Pengaruh Latihan Power Kaki Terhadap Kecepatan Tendangan Sabit Pada Atlet Pencak Silat Persaudaraan Setia Hati Terate di SMP Nurul Falah Kota Pekanbaru. Jurnal Akrab Juara, 5(1), 43-48.

Tofikin., Damrah., \& Nurmai, E. (2019). Pengaruh Daya Ledak Otot Tungkai, Kecepatan Dan Kelincahan Terhadap Kecepatan Tendangan Sabit Pada Atlet Pencak Silat Persaudaraan Setia Hati Terate di Kota Pekanbaru. Jurnal Pendidikan Rokania, 4(2), 209-219. https://doi.org/10.37728/jpr.v4i2.213

Wilujeng, W. A. (2013). Hubungan Kecepatan Terhadap Kecepatan Tendangan Sabit di SMP Muhammadiyah 2 Surabaya (Studi Pada Siswa Ekstrakurikuler Pencak Silat Tapak Suci). Jurnal Pendidikan Olahraga dan Kesehatan, 1(3), 584-587. 